\title{
Changing Times: Problematising Social Science Curriculum Implementation
}

\author{
Stefanie Biancotti
}

Kelsey Halbert

James Cook University

etropic 14.1 (2015): 13-20. http://www.reefandleaf.com.au/etropic.html \& http://www.jcu.edu.au/etropic

\begin{abstract}
By 2016, all schools across Australia will have transitioned from state-based to national curricula. Given the current dynamic period of curriculum change that schools are undergoing, there is a need to investigate how this change is implemented by and impacts on teachers. This research investigates the implementation of Australian History and Geography curriculum initiatives by a junior secondary school department (Years 7-10) in North Queensland. It systematically and critically reviews the Australian curriculum implementation processes and outcomes, within one Social Science department, through a case study methodology (Koshy, 2010; Yin, 2003). Actor Network Theory (ANT) (Fenwick \& Edwards, 2010) will be utilised as the theoretical framework for this research. The Actor Network theoretical framework will identify the actors (including lead researcher, teachers, administrators and objects such as Curriculum into the Classroom (C2C) materials) in the curriculum translation network and how the interactions between them shape the network and its processes. This article explores the historical context of curriculum change, maps the network of History curriculum actors and then details some of the implications that have emerged such as redefining the place of the History and Geography disciplines, the place of particular actors and the enabling and constraining factors in actors' engagement and agency during the implementation. Researcher observations, interview and survey data provide insights into the ways in which teachers shape their own professional practices in response to curriculum change.
\end{abstract}

Keywords: History Curriculum, Geography Curriculum, Case Study, Actor Network Theory

\section{Introduction}

The focus of this paper is to explore the historical understanding of curriculum change in the Social Science disciplines and then in light of this understanding, outline the initial constraints faced by the network in one Social Science department. Adoption of an actor network theory in unison with a case study methodology will allow for an examination of how the network or the 'community of co-inquirers' emerges and evolves over time in the common pursuit of a successful History and Geography curriculum implementation. This research will therefore examine the different aspects of the network's membership, the interactions and actions between the members (human and non-human) during the different phases of curriculum implementation and the outcomes of such interaction. It is currently a 
very dynamic context within which to observe the implementation of the Australian national History and Australian national Geography curriculum. Some of the factors shaping curriculum translation include relocation of Year 7 to secondary schools in Queensland, History and Geography supplanting Study of Society and the Environment (SOSE), and the strong push from Education Queensland in terms of pedagogical emphases (explicit teaching, differentiation and literacy).

\section{Curricula Transition}

School curricula in the Social Sciences have transitioned over time from separate disciplinary approaches to multi-disciplinary approaches and are now in the process of converting back to a separatist approach again. Global or grand narrative History predominated in schools during the early and middle 20th century. It relied on the reproduction of unquestioned narratives, emphasising great men and events, enduring tradition and chronology (Hoepper \& Quanchi, 2000; Harris, 2008). History in the 1960s was generally perceived as an academic subject that only suited students who would be continuing on to university (Taylor, 2000). History in the mid-1960s came under criticism from curriculum developers and theorists in both the United Kingdom and Australia because of its perceived lack of relevance to the lives of school students (Taylor, 2000). It was also more difficult for students to identify the value of History for future employability options given this perceived lack of relevance (Allen, 2008). History education in schools was also criticised for emphasising content at the expense of process (Sylvester, 1994; Slater, 1989; Taylor, 2000). History was perceived as:

Irrelevant because (a) it would not get students a job; (b) it was mainly about dead people, so studying history was of no consequence since it could not change anything and (c) school history reinforced traditional cultural, social and political values. (Taylor, 2000)

The New History shifted away from an emphasis on content towards a more balanced approach between content and a new methodological or skills-based approach (Little \& Mackinolty, 1977; Taylor, 2000). The New History of the 1970s coincided with Social Studies - a multidisciplinary perspective that focused on understanding social issues across the Humanities that was perhaps reflective of the socio-cultural changes over the 1960s and 1970s and how they influenced schooling.

Similarly, Geography emphasised a 'capes and bays' approach in the first half of the twentieth century which primarily saw a focus on geographical knowledge (content) such as the location and names of places (major towns, capital cities, etc.) and geographical features (major river systems and the highest mountain systems, etc.) (Harris, Harrison \& McFahn, 2012; Ferrari, 2006). Throughout most of the 1960s the teaching of Geography consequently focused on Physical Geography or Regional Geography. The main emphasis in Geography at the time was on the transmission of natural heritage through the intrinsic appeal of Geography because of the creation of awe and wonder of the world in which students lived (especially through the inclusion of fieldwork) (Harris, Harrison \& McFahn, 2012). This approach saw students writing profiles of countries based on subheadings such as population, climate, vegetation and land use (Ferrari, 2006). The key limitation of this approach is in itself how it is predominantly based on factual knowledge rather than inquiry (Harris, Harrison \& McFahn, 2012). Therefore a 'new' type of Geography was created which focused on a more scientific and theoretical approach in the late 1960s and 1970s (e.g. the study of 
spatial processes and patterns to explain human settlement) (Harris, Harrison \& McFahn, 2012). This type of Geography readily applied to Human Geography but also applied to some elements of Physical Geography as it saw greater use of data collection and hypothesis testing (Harris, Harrison \& McFahn, 2012). The addition of environmental concerns to Geography in the 1980s saw a more social issues and values-based approach which was a result of a rise in the Green Movement (Harris, Harrison \& McFahn, 2012; Ferrari, 2006).

In 1991, the Australian Education Council (AEC) confirmed the creation of eight Key Learning Areas (KLAs) for the compulsory years of schooling: English, Science, Mathematics, Languages Other Than English (LOTE), Technology, Studies of Society and Environment (SOSE), the Arts and Health and Physical Education (HPE) (Marsh, 2004). The Australian Education Council, Curriculum and Assessment Division (AECCAD, 1992) defined SOSE as 'the study of people as social beings as they interact with one another and with the natural and social environment in various places throughout time' (p. 4). The SOSE Key Learning Area (KLA) enabled an investigation of interdisciplinary topics relevant to students and their communities (at local, national and international levels) in order for them to 'practice critical and creative thinking, problem solving and decision making in real-life and lifelike contexts' (QSCC, 2001, p. 15). SOSE was seen as a discipline that promoted a higher level of thinking. According to Henderson (2005), "SOSE stems from earlier attempts to foster critical thinking and intellectually rigorous inquiry-based learning in the Social Sciences curriculum.” By 1993, History and Geography had been subsumed into the SOSE KLA in Queensland (Harris-Hart, 2008b).

However in spite of growing recognition at all levels of the need for interdisciplinary approaches to addressing social and environmental issues (Strachan, 2009; Bammer, 2005; DEWHA, 2009), the delivery of SOSE has been subjected to substantial criticism. SOSE has been criticised by academics for being taught as either a "jigsaw of separate disciplines or as generalist Social Studies” (Harris, 2008, p. 281). It has been branded as "anti-intellectual” (Powell, 1997, p. 50), “a muddled contrivance” (Powell, 1997, p. 49), “fuzzy” and even “mickey-mouse” (Tudball, 2008, p. 63; Harris-Hart, 2008a, p. 75). Lidstone (2006, p. 1) declared that the “integrated Social Studies doesn't do History well, it doesn't do Geography well, and it doesn't do citizens-type things well - very quickly becoming a hodgepodge.” Undoubtedly, such negative views of SOSE have assisted in the rationalisation for a separate History and Geography approach in the Australian curriculum.

\section{Case Study Methodology}

This research adopts a participant researcher case study approach within an actor network theoretical framework (Law, 1999) to investigate the translation of History and Geography national curriculum at a government secondary school in regional North Queensland. It aims to investigate the nature of curriculum translation processes over a short period of time involving the constitution of the curriculum network, and the interactions between actors (Social Science Subject Area Coordinator, faculty members, school administrators and critical friends) and non-human agents (Harris \& Marsh, 2005). Non- human agents included documents for History and Geography (Australian Curriculum, Assessment and Reporting Authority (ACARA), 2012), online auditing tools provided by the Queensland Studies Authority (QSA, 2012) and online 'Curriculum into the Classroom' (C2C) units that were made available through Education Queensland's OneSchool (EQ, 2011). The actor network theoretical framework (Fenwick \& Edwards, 2010) was most appropriate to illuminate these 
interactions and translations. Actor networks are not fixed entities which are constituted by actors; instead they are "fluid and contested definitions of identities and alliances that are simultaneously frameworks of power” (Nespor 1994, 9). The study also aims to identify what enabled and constrained agency on the part of actors in the network articulating with a dynamic curriculum context involving national, state and school imperatives.

A descriptive case study methodology intends to draw out the richness of the research site and interactions and qualitative methods allow for that depth to evolve. A descriptive case study is not an expression of a cause-effect relationship instead it covers the scope and depth of the case being described (Yin, 2003). The proximity of the researcher to the participants also reveals subtleties and complexities in relationships that may go undetected through the use of quantitative research methods (Burns, 2000). Key qualitative data sources that this research sees as most appropriate are researcher observations, survey data, interview data and documents.

The school involved in the research project has been assigned a pseudonym in order to protect its anonymity. Western High School is a $\mathrm{P}-12$ government school that currently caters for approximately 1700 students but has the facilities for expansion to 2100 students. The key people involved in the network under consideration were the eleven Social Science teachers, the Social Science Subject Area Coordinator, the English, Social Science, LOTE and Literacy Head of Department, the Deputy Principal and Principal. Actor network theory was used to make sense of the relationships of power between people and objects in the network and how they are represented in the curriculum, managerial and academic discourses.

\section{Process of Translation}

The process of translation "the mechanism by which the social and natural worlds progressively take form” (Callon, 1986, p. 19) can be traced through a series of four moments in which actors in the social and natural worlds are defined and mobilised, namely: problematisation; interessement/interposition; enrolment; and mobilisation (Callon, 1986). In the phase of problematisation the researcher sought to become indispensable to other actors in the network by "defining the nature and the problems of the latter and then suggesting that these would be resolved if the actors negotiated the 'obligatory passage point' of the researchers' programme of investigation” (Callon, 1986, p. 1). For the purpose of this paper the problems involved in the phase of problematisation will be outlined.

The initial problem (and the focus of this paper) appears to be the need to redefine the 'place' of History and Geography in terms of status and significance. The erosion of status due to the change to SOSE meant that it was hard for some staff to understand the need for History and Geography to both have time in the school curriculum as they felt it was still one discipline. Especially as History is compulsory until the end of Year 10 while Geography is only compulsory until the end of Year 8, meaning that greater significance or value was given to the discipline of History. The blurring of lines between Science and Geography in terms of Environmental Science also meant that it was hard for some staff to distinguish the need for the Geography discipline. Furthermore, neither subject is a prerequisite for entry to most universities. An absence of necessity for students to study them for post-school pathways also contributes to the perceived lower status of the discrete disciplines. Therefore a potential consequence of students not studying History or Geography will be that they will have a 
limited understanding of their own country (both historically and geographically) and the growing importance of the interrelationship with neighbouring countries and the rest of the world and would therefore not be as prepared as they could to become active Australian citizens.

Another problem for the case study school was how to redefine the role of SOSE or generalist Social Science teachers as History teachers and Geography teachers. SOSE teachers were not specialists in all key historical or geographical skills but were now being asked to align themselves with one of the disciplines. Likewise, some teachers had not trained in either History or Geography but were expected to teach these disciplines. Unfortunately, in some schools non-specialist teaching staff had to teach History or Geography if they were the only teacher available on that teaching line. And sometimes specialist staff would not be able to teach History or Geography if they were needed to teach another discipline deemed more important on that line.

\section{Implications of Curriculum Change}

Implications of an Australian curriculum with separate History and Geography disciplines may influence the status of these disciplines amongst the wider Australian community. In the United Kingdom a rise in the status of Social Science disciplines was seen following the introduction of a separate approach to the Social Sciences in the national curriculum program and the introduction of the 'English Baccalaureate' program which encourages students to study more 'academic' disciplines (Harris, Harrison \& McFahn, 2012). While it is too premature to see the effect on the status of History and Geography as separate disciplines in Australia, the separate approach to the Social Sciences in the Australian curriculum will most likely result in the demise of SOSE in Queensland and other cross-curricula Social Science/Humanities disciplines within Australia.

The perspectives of actors in the network to the change away from SOSE echoed debates about the breadth versus depth of knowledge. Teacher 3 felt that SOSE was "just too itty bitty, bits of this and bits of that and it never really had a very clear structure." Similarly, Teacher 4 said "that the character of SOSE is that it was very generalised...it was all very watered down unfortunately and very indistinct." Clearly, the place for SOSE no longer exists as a part of the state or national curriculum as Teacher 1 stated:

Is there a place for SOSE? Not anymore. Do we go into our strands and our understanding of those discrete subjects with a skill set and knowledges and so forth? Yes, we do do that and that can only benefit students.

Similarly, Administrator 2 supported the notion of History and Geography as discrete subjects as a "far more appropriate course of study than the combined SOSE which seemed to lack clear direction." Notably, Administrator 1 also supported the shift because "the fact that they're discrete disciplines allows for more depth and focus rather than having a discipline that's combined." There was clear support from the school administrators to engage in an approach that valued both History and Geography, as evidenced by their decision to make History and Geography compulsory until the end of Year 10. In turn, there would be a strengthening of the associations of the actors within the network. For despite there being different reasons for the shift towards discrete disciplines within the Social Sciences, there was consensus amongst staff within the school that this shift was a good decision. 
By making the Social Science disciplines compulsory in the junior years of high school meant that other elective subjects would lose time on the timetable and in turn those teachers would be expected to teach the junior Social Science classes. Therefore another challenge that was raised in curriculum implementation was that a large number of teachers were teaching outside their teaching areas. This was due to the growing shortage of suitably qualified Geography teachers in Australia (Kleeman, 2011). A survey conducted by Kleeman in late 2010 of Australian universities revealed that fewer than 150 pre-service teachers graduated with Geography as their first (principal) teaching area (Kleeman, 2011). Similarly Teacher 2 felt that teachers who were trained in teaching SOSE rather than History or Geography may not necessarily "have been familiar with some of the information and detail that's needed in the other area." Teacher 5 stated:

My major concern is the fact that there will be a lot of teachers required to teach in these areas that don't have a clue... obviously there are going to be teachers not trained in that area that will be required to teach this and there is no extra time given for preparation.

Teacher 5 and Middle Manager 1 also highlighted that this lack of specialist staff would impact on those teachers directed to teach as it would create a more stressful environment as both staff and students would struggle. Middle Manager 1 stated:

The data is very clear with classroom results that when you have a specialist teacher in front of that class, kids do well. When you don't, you have a lot of behavioural issues, you have lower class results or students who should be achieving a hell of a lot more than just gliding along - Cs, even failing when they shouldn't be.

It became apparent that it was as difficult to motivate the teachers who were without the academic training in the specified discipline as it was to ensure that they were teaching the content and skills correctly so that the students gained the most from the discipline.

Therefore, it was vital that the necessary professional development and support was offered from other teachers within the discipline to these staff members to try and assist them during this implementation phase because a lack of support would cause a clear breakdown in the network.

\section{Conclusion}

A preliminary conclusion is that the shift away from SOSE has been seen as beneficial by the network in returning status and value to the discrete disciplines of History and Geography. However, time constraints and the lack of suitably qualified staff may lead to non-specialist staff having to teach History and Geography which would be just as detrimental to the discrete disciplines as had been the lack of status. This article has briefly explored some of the factors that have emerged in the curriculum change process. Such research contributes to the systematic and critical reviews of the Australian national curriculum implementation processes and outcomes. Evidently, Australia is experiencing a very dynamic period of curriculum change and such change demands ongoing exploration into the teacher and student experience. 


\section{Works Cited}

Allen, B. (2008). School history and Australian history: Dead on the vine, or signs of new growth? Curriculum Perspectives, 28 (1), pp. 57-62.

Australian Curriculum, Assessment and Reporting Authority. (2012). ACARA About Us. Retrieved June 11, 2012, from Australian Curriculum, Assessment and Reporting Authority Web site: http://www.acara.edu.au/about_us/about_us.html

Australian Education Council, Curriculum and Assessment Division. (1992). Studies of society and environment for Australian schools. Proposed draft for consultation. Carlton South, Vic: Australian Education Council.

Bammer, G. (2005). Integration and Implementation Sciences: Building a New Specialisation. Ecology and Society. 10(2), p. 6. [Data File]. Retrieved June 2, 2009, from the Ecology and Society Web site: http://www.ecologyandsociety.org/vol10/iss2/art6/

Burns, R. (2000). Introduction to research methods. (4th ed.). South Melbourne: Longman.

Callon, M. (1986). Some Elements of a Sociology of Translation: Domestication of the Scallops and the Fishermen of St Brieuc Bay. pp. 196-233 in Power, Action and Belief: A New Sociology of Knowledge, edited by John Law. London: Routledge \& Kegan Paul. [Data File]. Retrieved October 19, 2014, from the BSCW shared workspace server Web site: https://bscw.uniwuppertal.de/pub/nj_bscw.cgi/d8022008/Callon_SociologyTranslation.pdf

Department of the Environment, Water, Heritage and the Arts. (2009). Living sustainably: The Australian governments national action plan for education for sustainability. [Data File]. Retrieved December 10, 2009, from the Department of the Environment, Water, Heritage and the Arts Web site: http://www.environment.gov.au/education/nap

Education Queensland (2011). Curriculum into the classroom. Retrieved December 18, 2011, from the OneSchool Web Site: http://oslp.eq.edu.au

Fenwick, T., \& Edwards, R. (2010). Actor-network theory in education. London: Routledge. Ferrari, J. (2006, September 28). The geography wars. Retrieved May 29, 2009, from The Australian Web site: http://www.theaustralian.news.com.au/story/0,20876,2048710928737,00.html

Harris, C. (2008). Time perspectives: Examining the past, present and futures. In C. Marsh (Ed.), Study of society and the environment: Exploring the teaching possibilities. (pp. 268-290). Frenchs Forest: Pearson Education Australia.

Harris, R. Harrison, S. \& McFahn, R. (2012). Cross-curricular teaching and learning in the secondary school: Humanities: History, Geography, Religious Studies and Citizenship. London: Routledge.

Harris-Hart, C. (2008a, April). History and SOSE: Where to now? Curriculum Perspectives Journal Edition, 28 (1), 75-81.

Harris-Hart, C. (2008b, April). Journal: History versus SOSE: Is that the question? Curriculum Perspectives Journal Edition, 28 (1), 55-56.

Harris, C., \& Marsh, C. (2005). Analysing curriculum change: Some reconceptuaised approaches. In C. Harris, \& C. Marsh (Eds.), Curriculum developments in Australia: Promising initiatives, impasses and dead-ends (pp. 15-38). Adelaide: Openbook Publishers.

Henderson, D. (2005). What is education for? Situating history, cultural understandings and studies of society and environment against neo-conservative critiques of curriculum reform. Australian Journal of Education, 49 (3), 306-319. 
Hoepper, B., \& Quanchi, M. (2000). History in years 1 to 10: Studies of society and environment key learning area. Retrieved June 1, 2009, from The Queensland Studies Authority Web site:

http://www.qsa.qld.edu.au/downloads/publications/research_qscc_sose_history_00.doc

Kleeman, G. (2009). Through the eyes of others: The role of curriculum perspectives in Australian school geography. Geographical Education, 22, 18-27.

Koshy, V. (2010). Action research for improving educational practice: A step-by-step guide. (2nd ed.). London: SAGE Publications Ltd.

Law, J. (1999). After ANT: Topology, naming and complexity. In J. Law, \& J. Hassard (Eds.), Actor network theory and after (pp. 1-14). Oxford: Blackwell Publishers.

Lidstone, J. (2006, October 19). Focus: Geography’s place in today’s schools. Futureminds(1).

Little, N. \& Mackinolty, J. (Eds.) (1997). A new look at history teaching. Sydney: History Teachers' Association of New South Wales.

Marsh, C. J. (2004). Key concepts for understanding curriculum. (3rd ed.). London: RoutledgeFalmer.

Nespor, J. (1994). Knowledge in Motion: Space, Time and Curriculum in Undergraduate Physics and Management. (1st ed.), Oxon: Routledge.

Queensland School Curriculum Council. (2001). Studies of society and the environment: Years 1 to 10 sourcebook guidelines. [Data File]. Retrieved April 8, 2010, from the Queensland Studies Authority Web site: http://www.qsa.qld.edu.au/downloads/p9/kla_sose_sbg.pdf

Queensland Studies Authority (2012). Australian curriculum auditing tools: History. Retrieved May 30, 2012 from The Queensland Studies Authority Web Site: http://www.qsa.qld.edu.au/

Powell, J. (1997). The pulse of citizenship: reflections on Griffith Taylor and 'nationplanning'. Australian Geographer, 28(1), 39-52.

Slater, J. (1988). The politics of history teaching. London: Institute of Education.

Strachan, G. (2009). Systems thinking. In A. Stibbe (Ed.) The handbook of sustainability literacy: Skills for a changing world. pp. 1-4. Dartington: Green Books.

Sylvester, D. (1994). Change and continuity in history teaching 1900-93. In H. Bourdillon (Ed.) Teaching history. London: Routledge.

Taylor, T. (2000, May). The future of the past - Final report of the national inquiry into school history. Retrieved June 8, 2009, from The Department of Education, Employment and Workplace Relations Web site: http://www.dest.gov.au/sectors/school_education/publications_resources/national_inquir y_into_school_history

Tudball, L. (2008, April). History versus SOSE: Revisiting the old curriculum debate in new ways. Curriculum Perspectives Journal Edition, 28(1), 63-67.

Yin, R. K. (2003). Applications of case study research. (2nd ed.). Thousand Oaks: CA: Sage. 